\title{
SOIL PREPARATION AND NUTRIENT LOSSES BY EROSION IN THE CULTURE OF CUCUMBER
}

\author{
Nelson Moura Brasil do Amaral Sobrinho*; Nelson Mazur \\ UFRRJ/IA - Depto. de Solos, BR 465, km 7 - 23890000 - Seropédica, RJ - Brasil. \\ *Corresponding author <nelmoura@ufrrj.br>
}

\begin{abstract}
Minimum tillage reportedly reduce erosion, avoid soil degradation and improve crop productivity. This study aimed to determine how tillage operations may affect either nutrient accumulation or nutrient losses by erosion. The study was, carried out from December, 2000 to March, 2001, in the watershed of the Caetés River, in Rio de Janeiro State, Brazil ( $\left.22^{\circ} 25^{\prime} 43^{\prime \prime S}, 43^{\circ} 25^{\prime} 07^{\prime \prime W}\right)$. The experiment was set up in sandy clay Kandiudult soil, 60\% slope, under cucumber (Cucumis sativus L.) crop. Soil samples were collected before planting and after harvest, on $22.0 \times 4.0 \mathrm{~m}$ Greeoff plots. After each rainfall, fine sediments carried by runoff were deposited into two collecting tanks in a row, installed at the end of each plot, and were later dried, weighed and stored for analyses. Treatments $(n=4)$ were characterized by different tillage systems: (i) downhill plowing followed by the burning of crop residues (DPB); (ii) downhill plowing with no burning of the crop residues (DPNB); (iii) animal traction contour plowing, with strips of guinea grass planted at a spacing of $7.0 \mathrm{~m}$ (AT); and (iv) minimum tillage (MT). Samples of the soil-plowed layer were collected before planting and after harvest, between the rows and from the plants. Total concentration of $\mathrm{Ca}, \mathrm{Mg}, \mathrm{K}$ and $\mathrm{P}$ were determined after extraction with nitric perchloride digestion. Labile $\mathrm{P}$ and exchangeable $\mathrm{K}$ were extracted with the Mehlich 1 extractant solution. The MT system reduced losses of both exchangeable bases (15\%) and P (8\%), and affected the distribution of labile and organic P. Crop residues left on soil surface in the MT system, resulted in increased organic matter content. Downhill plowing, the most used tillage operation in the region, resulted in the greatest losses of $\mathrm{Ca}, \mathrm{Mg}, \mathrm{K}$, and $\mathrm{P}$.
\end{abstract}

Key words: watershed of the Caetés, fractionation of $\mathrm{P}$, losses due to erosion

\section{PREPARO DO SOLO E PERDA DE NUTRIENTES POR EROSÃO NA CULTURA DO PEPINO}

\begin{abstract}
RESUMO: O cultivo mínimo reputadamente reduz a erosão, evita a degradação do solo e melhora a produtividade das culturas. Este trabalho teve por objetivo determinar a influência de diferentes métodos de preparo do solo sobre o acúmulo e perdas por erosão de nutrientes. O experimento foi realizado na microbacia de Caetés, município de Paty do Alferes RJ, $\left(22^{\circ} 25^{\prime} 43^{\prime \prime S}, 43^{\circ} 25^{\prime} 07^{\prime \prime O}\right)$ durante os meses de dezembro de 2000 a março de 2001 no ciclo de cultivo do pepino (Cucumis sativus L.). O experimento foi localizado em Argissolo Vermelho Amarelo, intermediário latossólico textura argila arenosa/argilosa e declividade de $60 \%$. Foram instaladas parcelas do tipo Wischmeier, numa área de 22,0 $\times 4,0 \mathrm{~m}$ com diferentes sistemas de preparo de solo. Ao final de cada parcela foram instalados dois tanques para o armazenamento das águas pluviais e dos sedimentos carreados pela enxurrada. Os tratamentos $(n=4)$ utilizados foram: (i) aração com trator morro abaixo e queima dos restos vegetais (MAQ); (ii) aração com trator morro abaixo não queimado com restos de vegetação natural entre as linhas (MANQ); (iii) aração com tração animal em nível, faixas de capim colonião a cada 7,0 m (AA) e (iv) cultivo mínimo (CM). Nas linhas e nas covas de cada parcela foram coletadas amostras da camada arável do solo antes do plantio e depois da colheita. Após cada chuva os sedimentos carreados pela erosão foram recolhidos, secos, pesados e guardados para posterior análise. As concentrações totais de $\mathrm{Ca}, \mathrm{Mg}, \mathrm{K}$ e $\mathrm{P}$ em solo e sedimentos foram determinadas em extratos nitro perclóricos. O CM reduziu as perdas das bases trocáveis e do $\mathrm{P}$ e também influenciou na distribuição nas formas lábil e orgânica de $\mathrm{P}$. O aproveitamento dos resíduos vegetais, na parcela sob $\mathrm{CM}$, propiciou aumento no teor de matéria orgânica. O tratamento MAQ, típico da região, foi o que apresentou as perdas mais elevadas de Ca, $\mathrm{Mg}, \mathrm{K}$ e $\mathrm{P}$.

Palavras chave: microbacia de Caetés, fracionamento de fósforo, perdas por erosão
\end{abstract}

\section{INTRODUCTION}

One of the most used tillage operations in Brazil is the plowing with furrow slices, known to degrade soil physical conditions (Núñez, 1997). On the other hand, minimum tillage operations are used to reduce erosion and avoid soil degradation, enhancing crop productivity. In conventional tillage, nutrients are uniformly incorpo- 
rated into the soil, while in minimum tillage fertilizers are applied to the soil surface, which results in the accumulation of fertilizers on the soil surface, added of nutrients derived from crop residues. (Klepker and Anghinoni, 1995).

Santos et al. (2003) reported the accumulation of exchangeable $\mathrm{Ca}^{+2}, \mathrm{Mg}^{+2}$ and $\mathrm{K}^{+}$, and available phosphorus (P), on the top soil layer after three years of no till, but no significant differences in soil $\mathrm{pH}$ were observed between conventional and no-tillage systems. In steepsloped croplands, $\mathrm{P}$ is lost mostly due to erosion (Resende et al., 1996). The phosphorus carried into water systems may be either in the soluble or protected form. Since P is strongly adsorbed to clay, the highest portion of $\mathrm{P}$ carried by the water in croplands is in the adsorbed form (Sharpley \& Smith, 1994).

The Paty do Alferes county, in the mountains of Rio de Janeiro State, is an agricultural area. About $40 \%$ of the tomatoes (Lycopersicon esculentum Mill.) produced in the State are grown in Paty de Alferes, as well as other crops, such as cabbage, cucumber, peas, sweet pepper, etc. Despite great investments, local agricultural production has decreased over the last decade, particularly due to deforestation and the use of unsustainable agricultural practices. The use of non-conservationist practices, such as plowing up and down slopes $\geq 45 \%$, results in high losses of soil and nutrients (Núñez et al., 1999; Santos, 2001; Santos et al., 2002; 2003. This study targeted (i) estimating both accumulation and losses of soil nutrients due to tillage erosion and (ii) determining how tillage operations affect the separation of chemical forms of $\mathrm{P}$.

\section{MATERIAL AND METHODS}

A four-months study, set up in the watershed of the Caetés river evaluated soil losses caused by heavy rainfall, under cucumber (Cucumis sativus L.) crop. Plots were installed on a sandy clay Kandiudult soil, typical for this region, $60 \%$ slope. Fertilizers usage is showed in Table 1. The runoff plot was established according to Wischmeier design, $22.0 \mathrm{~m}$ length by $4.0 \mathrm{~m}$ width $\left(88 \mathrm{~m}^{2}\right)$. Plots were limited by metal sheets placed $40 \mathrm{~cm}$ deep in the soil, spaced $4.0 \mathrm{~m}$. The runoff was collected directly to the end of the plot and then to a water tank, were samples were collect after every rainfall event resulting in runoff. The volume of the suspension in the tank was measured for latter calculations and the sample was taken to the laboratory for analysis. Soil was then weighted to estimate the amount lost by erosion. At the end of the crop cycle, all soil sediments samples collected were proportionally mixed according to the losses estimated for each rainfall, and a composite soil sample transported by runoff was obtained for each plot.

Field trials compared four tillage systems: (i) downhill plowing followed by the burning of crop residues (DPB); (ii) downhill plowing with no burning of the crop residues (DPNB); (iii) animal traction contour plowing, with strips of guinea grass (Panicum maximum Jacq.) planted with a spacing of $7.0 \mathrm{~m}$ (AT); and (iv) minimum tillage (MT). Trials were set up in a randomized, complete block with four blocks and four treatments $(n=4)$. Fertilization and pest and weed control were the same for all the treatments. One composited sample (twenty individual samples) was collected from the plowed player (0$20 \mathrm{~cm}$ ) before planting and after harvest, between the rows and from the plants.

Dried soil and sediment samples were first sieved trough $2 \mathrm{~mm}$ sieve, milled in agate vessel, and stored for further analyses, total $\mathrm{Ca}, \mathrm{Mg}, \mathrm{K}$ and $\mathrm{P}$ contents, after the nitric perchloride digestion, using a digestion block and a mixture of $\mathrm{HNO}_{3}+\mathrm{HClO}_{4}$ (Tedesco et al., 1997). Labile $\mathrm{P}$ and exchangeable $\mathrm{K}$ were extracted with the Mehlich 1 solution; exchangeable $\mathrm{Ca}$ and $\mathrm{Mg}$ were extracted with $1.0 \mathrm{~mol} \mathrm{~L}^{-1} \mathrm{KCl}$ solution (EMBRAPA, 1997). For the determination of organic and inorganic $\mathrm{P}$ fractions in soil and sediment samples, a sequential extraction technique was used, as described in Bowman (1989). Organic carbon was analyzed by the Walkley Black wet digestion method (EMBRAPA, 1997). Statistical analyses were performed by the software SAEG 5.0, and Tukey test was used to compare means $(\alpha=0.05)$.

\section{RESULTS AND DISCUSSION}

Soil organic matter (OM) contents measured before planting and after harvest in the four tillage systems and the amount of soil lost by erosion $\left(\mathrm{kg} \mathrm{ha}^{1}\right)$ are shown in Table 2. The OM contents in DPB, DPNB and AT treatments were significantly lower than in the MT system,

Table 1 - Fertilization practices and rainfall along the cucumber (Cucumis sativus L.) cropping cycle.

\begin{tabular}{|c|c|c|c|c|c|}
\hline Fertilizer & $\begin{array}{l}\text { Amount } \\
\text { applied }\end{array}$ & $\mathrm{N}$ & $\mathrm{P}$ & $\begin{array}{c}\text { Total } \\
\text { precipitation }\end{array}$ & $\begin{array}{c}\text { Maximum } \\
\text { intensity }\end{array}$ \\
\hline & \multicolumn{3}{|c|}{ - kg ha ${ }^{1} \ldots$} & $\mathrm{mm}$ & $\mathrm{mm} \mathrm{h}^{-1}$ \\
\hline Cattle manure & 40,000 & 752 & 385 & 456 & 84 \\
\hline Castor bean manure & 2,000 & 70 & 14 & & \\
\hline Yoorin thermophosphate & 800 & & 49 & & \\
\hline $\mathrm{KCl}+\left(\mathrm{NH}_{4}\right)_{2} \mathrm{SO}_{4(1: 1)}$ & 140 & 14 & & & \\
\hline
\end{tabular}

Sci. Agric. (Piracicaba, Braz.), v.62, n.6, p.572-577, Nov./Dec. 2005 
that is, minimum tillage reduced soil losses compared to conventional tillage (Figure 1). The low OM contents observed in DPB and DPNB treatments may be related to soil losses due to organic matter erosion, which were observed to be about three to six times greater than losses observed in treatments AT and MT, respectively. High soil disturbance reduces soil aeration, humidity and temperature, also making soil aggregates very susceptible to breakdown, increasing the risks of surface exposure, and promoting crop residues breakdown and incorporation (Bayer \& Mielniczuk, 1997). Tillage systems are likely to have affected the rate of accumulation of organic matter, because of losses due to erosion (Figure 1) and OM mineralization; OM contents have already been found to be lower in tillage systems where soil was greatly disturbed (De Maria \& Castro, 1993).

The accumulation of both total and exchangeable $\mathrm{K}$ was significantly higher in MT than in the other three plowing systems (Table 3). Centurion et al. (1985) also

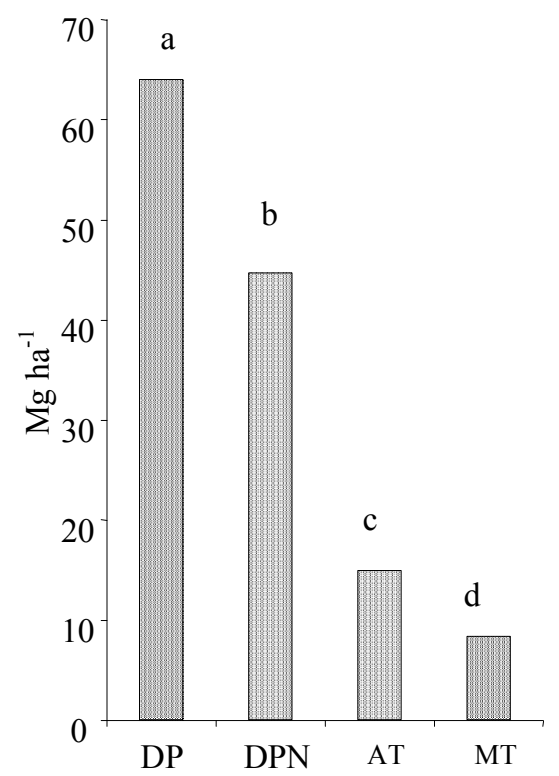

Figure 1 - Soil losses due to tillage erosion in cucumber (Cucumis sativus L.) crop (Letter in the columns do not differ Tukey test, $P<0.05)$. found minimum tillage systems to accumulate more exchangeable $\mathrm{K}^{+}$in the top $5 \mathrm{~cm}$ layer than in conventional tillage. High contents of $\mathrm{K}^{+}$also observed in subsurface may have resulted from high leaching. For the other tillage systems where there was soil disturbance, $\mathrm{K}$ was more uniformly distributed. Despite the decrease in the total K content after harvest, there was an increase in the exchangeable $\mathrm{K}$ content, both between rows and in the plants. In the first growth stages, the high contents of $\mathrm{K}$ adsorbed by plants caused a decrease in soil available $\mathrm{K}$ was contents; in the following stages, $\mathrm{K}$ was washed off the leaves and stalks by the rainfall, and accumulates in the soil (Klepker \& Anghinoni, 1995).

MT is known to reduce losses of K (Table 4). DPB system caused a great loss of K. Losses by leaching are also significant, since $\mathrm{K}$ has high solubility, especially in sandy soils. The accumulation of exchangeable $\mathrm{Ca}^{+2}$ and $\mathrm{Mg}^{+2}$ was also observed in the MT system (Table 3), despite the fact that no lime was applied before planting. The increase in the contents of those nutrients may be related to fertilization practices (Yoorin thermophosphate and manure) or to the crop residues left on the soil surface.

Soil $\mathrm{pH}$ increased in both no-till and mulch tillage systems, as well as the contents of $\mathrm{Ca}, \mathrm{Mg}$ and $\mathrm{K}$. Those findings may be associated to the release of nutrients by crop residues on the soil surface (Sidiras \& Pavan, 1985). Losses of $\mathrm{Ca}$ and $\mathrm{Mg}$ due to erosion were lower than losses of $\mathrm{K}$, and the lowest losses of those nutrients were observed in the MT system (Table 4).

Higher contents of total $\mathrm{P}$ were observed in the minimum tillage system, both between the rows and in the plants; the system favored $\mathrm{P}$ accumulation by reducing soil losses (Figure 1). Tillage system affected the distribution of labile, organic and inorganic $\mathrm{P}$ in the soil (Table 5). Higher contents of labile $\mathrm{P}$ were registered in the MT system, since greater soil disturbance in the other systems move likely increased $P$ availability.

Ultisols have clayey subsurface horizons, clay being mostly kaolinite and $\mathrm{Fe}$ and $\mathrm{Al}$ oxides (Núñez et al., 1999), with specific sites for $P$ adsorption. The more the

Table 2 - OM contents and loss due to tillage erosion under different systems*.

\begin{tabular}{|c|c|c|c|c|c|}
\hline \multirow[b]{2}{*}{$\begin{array}{c}\text { Tillage } \\
\text { system }\end{array}$} & \multicolumn{4}{|c|}{ Organic matter content } & \multirow[b]{2}{*}{$\begin{array}{l}\text { Soil loss due } \\
\text { to erosion }\end{array}$} \\
\hline & Between rows ${ }^{1}$ & Between rows ${ }^{2}$ & Plants $^{1}$ & Plants $^{2}$ & \\
\hline & - - & g & - & - & $\mathrm{kg} \mathrm{ha}^{-1}$ \\
\hline DPB & $26.7 \mathrm{~b}$ & $25.2 \mathrm{~b}$ & $28.8 b^{1}$ & $23.6 b^{2}$ & $1543 \mathrm{a}$ \\
\hline DPNB & $24.5 \mathrm{~b}$ & $24.1 \mathrm{~b}$ & $24.1 \mathrm{~b}$ & $17.9 \mathrm{c}$ & $1465 \mathrm{~b}$ \\
\hline AT & $28.3 \mathrm{~b}$ & $25.0 \mathrm{~b}$ & $30.0 \mathrm{~b}$ & $26.9 \mathrm{a}$ & $536 \mathrm{c}$ \\
\hline MT & $42.2 \mathrm{a}$ & $35.3 \mathrm{a}$ & $42.2 \mathrm{a}$ & $29.8 \mathrm{a}$ & $319 \mathrm{~d}$ \\
\hline
\end{tabular}

*Means followed by the same letters on columns do not differ (Tukey test; $P<0.05$ ).

${ }^{1}$ Before planting, ${ }^{2}$ After harvest 
Table 3 - Contents of exchangeable bases before planting and after harvest*.

\begin{tabular}{|c|c|c|c|c|c|c|}
\hline Tillage system & Exchangeable K & Total K & exchangeable $\mathrm{Ca}$ & Total Ca & Exchangeable $\mathrm{Mg}$ & Total $\mathrm{Mg}$ \\
\hline & \multicolumn{6}{|c|}{ - } \\
\hline & \multicolumn{6}{|c|}{ BETWEEN ROWS } \\
\hline & \multicolumn{6}{|c|}{ Before planting } \\
\hline DPB & $4.7 \mathrm{a}$ & $22.5 \mathrm{~b}$ & $19.6 \mathrm{~b}$ & $149.1 \mathrm{ab}$ & $117.7 \mathrm{~b}$ & $62.1 \mathrm{a}$ \\
\hline DPNB & $4.7 \mathrm{a}$ & $27.9 \mathrm{~b}$ & $19.9 \mathrm{~b}$ & $92.2 \mathrm{~b}$ & $11.7 \mathrm{~b}$ & $38.4 \mathrm{a}$ \\
\hline $\mathrm{AT}$ & $3.0 \mathrm{~b}$ & $23.3 \mathrm{~b}$ & $20.7 \mathrm{ab}$ & $112.9 \mathrm{ab}$ & $11.7 \mathrm{~b}$ & $50.7 \mathrm{a}$ \\
\hline \multirow[t]{2}{*}{ MT } & $5.3 \mathrm{a}$ & $34.6 \mathrm{a}$ & $22.1 \mathrm{a}$ & $158.7 \mathrm{a}$ & $12.9 \mathrm{a}$ & $69.7 \mathrm{a}$ \\
\hline & \multicolumn{6}{|c|}{ After harvest } \\
\hline DPB & $5.7 \mathrm{c}$ & $14.2 \mathrm{~b}$ & $11.4 \mathrm{a}$ & $52.4 \mathrm{a}$ & $11.2 \mathrm{a}$ & $33.8 \mathrm{ab}$ \\
\hline DPNB & $8.0 \mathrm{~b}$ & $15.8 \mathrm{~b}$ & $13.7 \mathrm{a}$ & $60.3 \mathrm{a}$ & $11.3 \mathrm{a}$ & $23.8 \mathrm{~b}$ \\
\hline AT & $8.0 \mathrm{~b}$ & $15.8 \mathrm{~b}$ & $10.0 \mathrm{a}$ & $52.0 \mathrm{a}$ & $11.3 \mathrm{a}$ & $40.9 \mathrm{ab}$ \\
\hline \multirow[t]{3}{*}{ MT } & $13.2 \mathrm{a}$ & $25.8 \mathrm{a}$ & $9.3 \mathrm{a}$ & $82.8 \mathrm{a}$ & $11.4 \mathrm{a}$ & $47.6 \mathrm{a}$ \\
\hline & \multicolumn{6}{|c|}{ PLANTS } \\
\hline & \multicolumn{6}{|c|}{ Before planting } \\
\hline DPB & $5.1 \mathrm{~b}$ & $33.3 \mathrm{a}$ & $20.7 \mathrm{a}$ & $125.6 \mathrm{~b}$ & $13.9 \mathrm{c}$ & $54.7 \mathrm{~b}$ \\
\hline DPNB & $5.2 \mathrm{~b}$ & $32.5 \mathrm{a}$ & $21.5 \mathrm{a}$ & $138.6 \mathrm{~b}$ & $14.9 \mathrm{~b}$ & $60.9 \mathrm{ab}$ \\
\hline AT & $3.7 \mathrm{c}$ & $28.3 \mathrm{a}$ & $24.7 \mathrm{a}$ & $153.0 \mathrm{~b}$ & $13.7 \mathrm{c}$ & $65.2 \mathrm{ab}$ \\
\hline \multirow[t]{2}{*}{ MT } & $6.2 \mathrm{a}$ & $37.9 \mathrm{a}$ & $24.4 \mathrm{a}$ & $136.8 \mathrm{a}$ & $15.6 \mathrm{a}$ & 80.9 a \\
\hline & \multicolumn{6}{|c|}{ After harvest } \\
\hline DPB & $12.2 \mathrm{~b}$ & $23.3 \mathrm{ab}$ & $08.4 \mathrm{ab}$ & $78.2 \mathrm{a}$ & $12.5 \mathrm{a}$ & $34.3 \mathrm{a}$ \\
\hline DPNB & $14.0 \mathrm{~b}$ & $16.7 \mathrm{~b}$ & $07.0 \mathrm{~b}$ & $55.0 \mathrm{~b}$ & $13.5 \mathrm{a}$ & $33.1 \mathrm{a}$ \\
\hline $\mathrm{AT}$ & $12.2 \mathrm{~b}$ & $15.8 \mathrm{~b}$ & $08.3 \mathrm{ab}$ & $65.4 \mathrm{ab}$ & $12.2 \mathrm{a}$ & $49.3 \mathrm{a}$ \\
\hline MT & $25.6 \mathrm{a}$ & $29.2 \mathrm{a}$ & $10.3 \mathrm{a}$ & $82.5 \mathrm{a}$ & $12.2 \mathrm{a}$ & $46.6 \mathrm{a}$ \\
\hline
\end{tabular}

*Means followed by the same letters on columns do not differ (Tukey test; $P<0.05$ ).

Table 4 - Losses of $\mathrm{K}, \mathrm{Ca}$ and $\mathrm{Mg}$ due to tillage erosion under four different systems*.

\begin{tabular}{lcccccc}
\hline Tillage system & Exchangeable $\mathrm{Ca}$ & Total $\mathrm{Ca}$ & Exchangeable $\mathrm{Mg}$ & Total Mg & Exchangeable $\mathrm{K}$ & Total $\mathrm{K}$ \\
\hline & $-18 \mathrm{a}^{1}$ & $75 \mathrm{a}$ & $16 \mathrm{a}$ & $41 \mathrm{a}$ & $32 \mathrm{a}$ & $198 \mathrm{a}$ \\
DPB & $13 \mathrm{~b}$ & $42 \mathrm{~b}$ & $11 \mathrm{a}$ & $20 \mathrm{~b}$ & $24 \mathrm{~b}$ & $100 \mathrm{~b}$ \\
DPNB & $5 \mathrm{c}$ & $17 \mathrm{c}$ & $4 \mathrm{~b}$ & $12 \mathrm{c}$ & $7 \mathrm{c}$ & $59 \mathrm{c}$ \\
AT & $2 \mathrm{~d}$ & $10 \mathrm{~d}$ & $2 \mathrm{~b}$ & $6 \mathrm{~d}$ & $5 \mathrm{c}$ & $32 \mathrm{~d}$ \\
MT & &
\end{tabular}

"Means followed by the same letters on columns do not differ (Tukey test; $P<0.05$ ).

soil is disturbed, the greater the contact between subsurface horizons and soluble phosphates, increasing the fixation of the most labile $\mathrm{P}$ into non-labile forms (Novais et al., 1985). Inorganic P accounted for almost $70 \%$ of total $\mathrm{P}$ in all the tillage systems, while in the MT system organic forms accounted for about $29 \%$ of total $\mathrm{P}$, and labile $\mathrm{P}$ for about $28 \%$ and $30 \%$, for samples collected between the rows and in the plants, respectively. Lower portions (14\% and $8 \%$ ) of this greatly available form were observed in the DPB system. A decreasing in the percents of organic $\mathrm{P}$ in samples collected after harvest was also observed, for the three conventional tillage systems. Organic P contents in the MT system remained around $28 \%$, because of the greater organic matter contents.

Remaining crop residues on the soil surface in the MT system favors the accumulation of OM (Figure 1), and consequently of organic $P$ (Table 3 ). Since most residues are P-rich, the decomposition and mineralization of organic P supply inorganic P for microbial assimilation, plant absorption, and interaction with mineral compounds. Organic P may either be stable in the $\mathrm{OM}$ or interact with the soil mineral compounds (Guerra, 1993).

The contents of organic and labile P fractions slightly increased in all systems, probably due to the mineralization and release of soil's organic P. The content of total P lost due to erosion was quite lower in the MT system than in the other three systems (Table 6). Losses of $\mathrm{P}$ in the DPB system were found to be 12 times greater than losses in the MT system. Just by leaving crop residues between the rows, as in the DPNB system, P total losses were reduced by $36 \%$ when compared to the traditional local system (DPB).

Minimum tillage system was more effective in conserving $\mathrm{P}$ applied to the soil, as it reduced P losses due to erosion. The second more effective system was AT, which suggests that little soil disturbance and the use of natural barriers are effective agricultural practices for soil 
Table 5 - Content of labile $\mathrm{P}$ and fractions of $\mathrm{P}$ in the systems, before planting and after harvest. Numbers in parenthesis indicate the percentage based on total $\mathrm{P}^{*}$.

\begin{tabular}{|c|c|c|c|c|}
\hline Tillage system & Labile P & Inorganic $\mathrm{P}$ & Organic $\mathrm{P}$ & Total P \\
\hline & \multicolumn{4}{|c|}{ - } \\
\hline & \multicolumn{4}{|c|}{ BETWEEN THE ROWS } \\
\hline & \multicolumn{4}{|c|}{ Before planting } \\
\hline MAQ & $33.3(14.6) \mathrm{b}$ & $161.8(71.0) b$ & $66.2(29.0) \mathrm{b}$ & $228.1 \mathrm{c}$ \\
\hline MANQ & $38.8(14.8) \mathrm{b}$ & $185.0(70.7) \mathrm{a}$ & $76.7(29.3) \mathrm{a}$ & $261.8 \mathrm{~b}$ \\
\hline AA & $39.6(18.6) \mathrm{b}$ & $151.1(70.9) b$ & $62.0(29.1) \mathrm{c}$ & $213.1 \mathrm{~d}$ \\
\hline \multirow[t]{2}{*}{$\mathrm{CM}$} & $78.8(28.9) \mathrm{a}$ & $193.2(70.8) \mathrm{a}$ & $79.7(29.2) \mathrm{a}$ & $268.6 \mathrm{a}$ \\
\hline & \multicolumn{4}{|c|}{ After harvest } \\
\hline MAQ & $27.0(14.6) \mathrm{b}$ & $145.8(78.9) \mathrm{c}$ & $39.0(21.1) \mathrm{d}$ & $184.8 \mathrm{c}$ \\
\hline MANQ & $27.0(12.4) b$ & $166.8(76.4) b$ & $51.5(23.6) \mathrm{b}$ & $218.2 \mathrm{~b}$ \\
\hline AA & $27.7(15.0) b$ & $140.5(76.2) \mathrm{d}$ & $43.9(23.8) \mathrm{c}$ & $184.4 \mathrm{c}$ \\
\hline \multirow[t]{3}{*}{$\mathrm{CM}$} & $76.9(30.9) \mathrm{a}$ & $179.2(71.9) \mathrm{a}$ & $70.4(28.3) \mathrm{a}$ & $249.6 \mathrm{a}$ \\
\hline & \multicolumn{4}{|c|}{ PLANTS } \\
\hline & \multicolumn{4}{|c|}{ Before planting } \\
\hline MAQ & $42.4(8.0) \mathrm{c}$ & $357.9(70.9) \mathrm{d}$ & $146.8(29.1) b$ & $504.7 \mathrm{~b}$ \\
\hline MANQ & $48.1(9.0) \mathrm{c}$ & $379.2(70.9) b$ & $155.3(29.1) \mathrm{ab}$ & $534.6 \mathrm{a}$ \\
\hline AA & $79.8(15.2) \mathrm{b}$ & $370.7(70.0) \mathrm{c}$ & $151.4(29.0) \mathrm{ab}$ & $522.2 \mathrm{ab}$ \\
\hline \multirow[t]{2}{*}{$\mathrm{CM}$} & $121.8(22.1) \mathrm{a}$ & $390.3(70.7) \mathrm{a}$ & $161.7(29.3) \mathrm{a}$ & $552.1 \mathrm{a}$ \\
\hline & \multicolumn{4}{|c|}{ After harvest } \\
\hline MAQ & $44.6(10.1) c$ & $347.8(78.6) \mathrm{c}$ & $94.7(21.4) \mathrm{d}$ & $442.5 \mathrm{~d}$ \\
\hline MANQ & $47.3(10.2) \mathrm{c}$ & $347.8(75.4) \mathrm{c}$ & $113.4(24.6) \mathrm{c}$ & $461.3 \mathrm{c}$ \\
\hline AA & $77.1(15.9) \mathrm{b}$ & $357.7(73.6) b$ & $128.3(26.4) b$ & $486.0 \mathrm{~b}$ \\
\hline $\mathrm{CM}$ & $110.8(21.6) \mathrm{a}$ & $369.0(71.6) \mathrm{a}$ & $146.4(28.4) \mathrm{a}$ & $515.3 \mathrm{a}$ \\
\hline
\end{tabular}

*Means followed by the same letters on the columns, for samples collected in the same place and in the same period, for each $\mathrm{P}$ chemical form, do not differ (Tukey test; $P<0.05$ ).

Table 6 - Losses of labile $\mathrm{P}$, organic and inorganic $\mathrm{P}$ due to tillage erosion. Numbers in parenthesis indicate the percentage based on total $\mathrm{P}^{*}$.

\begin{tabular}{lcccc}
\hline Tillage system & Labile $\mathrm{P}$ & Inorganic $\mathrm{P}$ & Organic $\mathrm{P}$ & Total P \\
\hline MAQ & $4.9(10.3) \mathrm{aD}$ & $29.2(62.0) \mathrm{aB}$ & $17.8(37.8) \mathrm{aC}$ & $47.0 \mathrm{aA}$ \\
MANQ & $3.3(11.1) \mathrm{bD}$ & $18.8(62.8) \mathrm{bB}$ & $11.1(37.2) \mathrm{bC}$ & $29.9 \mathrm{bA}$ \\
AA & $1.3(11.4) \mathrm{cD}$ & $7.4(65.9) \mathrm{cB}$ & $3.9(34.1) \mathrm{cC}$ & $11.2 \mathrm{acA}$ \\
CM & $0.5(13.0) \mathrm{dD}$ & $2.7(70.0) \mathrm{dB}$ & $1.2(30.0) \mathrm{dC}$ & $3.9 \mathrm{dA}$ \\
\hline
\end{tabular}

*Means followed by the same small letters on the columns, and capital letters on the rows, do not differ (Tukey test; $P<0.05$ ).

conservation and soil fertility sustainability. The results of this study clearly suggest that the DPB system, widely used in the studied watershed, is not sustainable.

\section{REFERENCES}

BAYER, C.; MIELNICZUK, J. Características químicas do solo afetadas por métodos de preparo e sistemas de cultura. Revista Brasileira de Ciência do Solo, v.21, p.105 112, 1997.

BOWMAN, R.A. A sequential extraction procedure with concentrated sulfuric acid and dilute base for soil organic phosphorus. Soil Science Society of America Journal, v.53, p.362 366, 1989.

CENTURION, J.F.; DEMATTÊ, J.L.I.; FERNANDES, F.M. Efeitos de sistemas de preparo nas propriedades químicas de um solo sob cerrado cultivado com soja. Revista Brasileira de Ciência do Solo, v.9, p.267 $270,1985$.

DE MARIA, I.C.; CASTRO, O.M. de. Fósforo, potássio e matéria orgânica em um latossolo roxo, sob sistemas de manejo com milho e soja. Revista Brasileira de Ciência do Solo, v.17, p.471 477, 1993.
EMPRESA BRASILEITA DE PESQUISA AGROPECUARIA. Manual de métodos de análise de solo. 2.ed.. Rio de Janeiro: EMBRAPA, CNPS, 1997. 212p.

GUERRA, J.G.M. Produção sazonal de Brachiaria Decumbens Stapf, conteúdo de fósforo orgânico e microbiano em solos tropicais de baixa fertilidade natural. Itaguaí: UFRRJ, 1993. 234p. (Tese - Doutorado).

KLEPKER, D.; ANGHINONI, I. Características físicas e químicas do solo afetadas por métodos de preparo e modos de adubação. Revista Brasileira de Ciência do Solo, v.19, p.395 401, 1995.

NOVAIS, R.F.; BAHIA FILHO, A.F.C.; RIBEIRO, A.C.; VASCONCELOS, C.A. Solubilização de fosfatos incubados com amostras de latossolo submetidas a diferentes números de revolvimento. Revista Brasileira de Ciência do Solo, v.9, p.23 26, 1985.

NÚÑEZ, J.E.V. Acúmulo e perdas por erosão de nutrientes e metais pesados afetado pelo metodo de preparo do solo. Seropédica: UFRRJ, 1997. 125p. (Dissertação - Mestrado).

NÚÑEZ, J.E.V.; AMARAL SOBRINHO, N.M.B.; PALMIERI, F.; MESQUITA, A A. Consequências de diferentes sistemas de preparo do solo sobre a contaminação do solo, sedimentos e água por metais pesados. Revista Brasileira de Ciência do Solo, v.23, p.981-990, 1999. 
RESENDE, S.B. de; RESENDE, M. Solos dos Mares de Morros: ocupação e uso. In: ALVAREZ, V.H.; FONTES, L.E.F.; FONTES, M.P.F. (Ed.) $\mathbf{O}$ solo nos grandes domínios morfoclimáticos do Brasil e o desenvolvimento sustentado. Viçosa: SBCS; UFV, DPS, 1996. p.261 288.

SANTOS, F.S. Contaminação de um Agroecossistema por Metais Pesados em Função do uso de Agroquímicos em diferentes Manejos Agrícolas. Seropédica: UFRRJ, 2001. 95p. (Tese - Mestrado).

SANTOS, F.S.; AMARAL SOBRINHO, N.M.B.; MAZUR, N. Influência de Diferentes Manejos Agrícolas na Distribuição de Metais Pesados no Solo e em Plantas de Tomate. Revista Brasileira de Ciência do Solo, Viçosa:, v.26, p.535-543, 2002.

SANTOS, F.S.; AMARAL SOBRINHO, N.M.B.; MAZUR, N. Consequências do Manejo do Solo na Distribuição de Metais Pesados em um Agrossistema com Feijão de Vagem (Phaseolus vulgarisL.). Revista Brasileira de Ciência do Solo, v.27, p.191-198, 2003.
SHARPLEY, A.N.; SMITH, S.J. Wheat tillage and water quality in the Southern Plains. Soil Tillage Research, v.30, p.33-38, 1994.

SIDIRAS, N.; PAVAN, M.A. Influência do sistema de manejo do solo no seu nível de fertilidade. Revista Brasileira de Ciência do Solo, v.9, p. $185286,1985$.

TEDESCO, M.J.; GIANELlO, C.; BISSANI, C.A.; BOHNEN, H.; VOLKWEISS, S.J. Análise de solo, plantas e outros materiais. 2.ed. Porto Alegre: UFRGS, Faculdade de Agronomia, Departamento de Solos, 1997. 174p.

Received October 25, 2004

Accepted November 03, 2005 